\title{
Implementasi Pendidikan Karakter dalam Pembelajaran IPS di Madrasah Aliyah
}

\author{
HANANG AR RASYID \\ MA Wahid Hasyim Yogyakarta \\ hanangarrasyid@gmail.com
}

\begin{abstract}
Abstrak
Penelitian ini bertujuan untuk mendeskripsikan pelaksanaan pendidikan karakter dalam pembelajaran IPS di MA Pondok Pesantren Wahid Hasyim dan menemukan faktor pendukung dan penghambat dalam proses pembentukan karakter siswa. Penelitian ini merupakan penelitian kualitatif. Data dikumpulkan melalui observasi, dokumentasi, dan wawancara. Hasil penelitian menunjukkan bahwa: (1) Pendidikan karakter dilaksanakan melalui kegiatan intrakurikuler dan ekstrakuriker, (2) Pendidikan karakter diimplementasikan dalam pembelajaran IPS mulai dari persiapan guru dalam pembelajaran hingga pembiasaan-pembiasaan di dalam kelas seperti datang tepat waktu, bersalaman dan membuka dan mengakhiri pelajaran dengan membaca Al-Qur'an (3) Metode yang digunakan guru IPS dalam penyampaian pendidikan karakter sebagian besar masih menggunakan metode ceramah sehingga respon siswa terhadap pelaksanaan pendidikan karakter belum maksimal (4) Faktor pendukung pelaksanaan pendidikan karakter dalam pembelajaran IPS diantaranya adanya tata tertib yang terpajang di setiap kelas, kultur sekolah, nilai kepesantrenan dan dukungan Kepala Sekolah dan Guru serta pihak yayasan, sedangkan faktor penghambatnya antara lain: sarana dan prasarana, dana dan pembiayaan, program, buku penunjang tentang pendidikan karakter.
\end{abstract}

Kata kunci: Pendidikan karakter, pembelajaran IPS.

\section{Abstract}

This study aims to describe the implementation of character education in teaching social studies in the MA PondokPesantren Wahid Hasyim and find the supporting and inhibiting factors in theprocess of students' character building. This study is a qualitative research. The results are as follows: (1) Character education is carried out through intracurricular and extracurrigular activities. (2) Character education is implemented in teaching social studies, ranging from the preparation of teachers in the learning habituation to the conditioning in the classroom, including coming to class on time, shaking hands, and opening and endingthe lesson by reading the Qur'an. (3) The method used by most of the social studies teachers in the delivering character education is the lecture method, so that students' responses to the implementation of character education is not maximal. (4) The factors supporting the implementation of character education in social studies teaching among others the rules which are displayed in every classroom, a school culture, values of kepesantrenan and supportsfrom principals and teachers as well as the foundation; while the inhibiting factors include: inadequate infrastructures, limited funding and financing, the non-supporting teaching program including the monotonous methods used by teachers in delivering teaching materials, limited supporting books on character education.

Keywords: character education, social studies. 


\section{PENDAHULUAN}

Fenomena yang terjadi dewasa ini menunjukkan adanya gejala kemerosotan moral yang sangat mengkhawatirkan. Kebenaran, kejujuran, keadilan, tolong menolong dan kasih sayang sudah mulai menjadi barang mahal dan tertutup oleh penyelewengan, penipuan, penindasan, saling acuh tak acuh, mengambil hak orang lain, seks bebas dan masih banyak tindakantindakan menyimpang lainnya. Ironisnya tindakan-tindakan menyimpang ini banyak dilakukan oleh sebagian generasi muda bangsa ini, meskipun jumlahnya sepersekian dari jumlah pelajar secara keseluruhan, namun hal tersebut telah sedikit memberikan catatan yang kurang baik akan kredibilitas dunia pendidikan. Para peserta didik sebagai penerus peradaban seharusnya bisa menunjukkan karakter yang baik sebagai implementasi nilai dari salah satu tujuan pendidikan itu sendiri.

Pendidikan pada dasarnya adalah proses panjang dalam rangka menghantarkan peserta didik menjadi seorang manusia yang memiliki kekuatan spiritual dan intelektual, sehingga dapat meningkatkan kualitas hidupnya di segala aspek dan mengalami pendidikan yang bercita-cita dan tujuan pasti (Ma'arif, 1997, p.63). Pendidikan bukan sekedar memanusiakan manusia, tetapi dengan jelas dan rinci sebagai upaya membina mental, melahirkan generasi, membina umat dan budaya serta memberikan prinsip-prinsip kemuliaan dan peradaban (Raharjo,1999, p.54).

Dunia pendidikan di Indonesia kini sedang memasuki masa-masa yang pelik. Kucuran anggaran pendidikan yang besar disertai berbagai program terobosan sepertinya belum mampu memecahkan persoalan mendasar dalam dunia pendidikan, yakni bagaimana mencetak alumni pendidikan yang unggul, yang beriman, bertaqwa, profesional, dan berkarakter. Oleh karena itu seperti negara berkembang lainnya, Indonesia kini sedang berusaha membangun karakter anak bangsa untuk memperbaiki citra bangsa sambil tetap mempertahankan identitas kulturalnya, proses ganda ini diusahakan dengan keseimbangan antara pertumbuhan dan pemerataan, sekaligus melestarikan pola kehidupan sosial budaya yang mendukung proses tersebut dalam rumusan yang lebih tepat dan sesuai. Indonesia sedang berusaha bagaimana memantapkan kelangsungan psikologis dan kerangka proses perubahan yang lebih luas dalam membangun peradaban

Pemerintah melalui Kementerian Pendidikan dan Kebudayaan sudah mencanangkan penerapan pendidikan karakter untuk semua tingkat pendidikan, dari SD sampai pada tingkat Perguruan Tinggi. Pembentukan karakter perlu dilakukan sejak usia dini. Munculnya gagasan program pendidikan karakter dalam dunia pendidikan di Indonesia, bisa dimaklumi, sebab selama ini dirasakan, proses pendidikan ternyata belum berhasil membangun manusia Indonesia yang berkarakter.

Koesoma (2010, p.250) mendefinisikan pendidikan karakter sebagai nilai-nilai dasar yang harus dihayati jika sebuah masyarakat mau hidup dan bekerja sama secara damai. Nilai-nilai seperti kebijaksanaan, penghormatan terhadap yang lain, tanggungjawab pribadi, perasaan senasib, sependeritaan, pemecahan konflik secara damai, merupakan nilainilai yang semestinya diutamakan dalam pendidikan karakter. Sedangkan Murphy, (2009, p.10) menyatakan bahwa: That character education: will help young people understand such core ethical values as fairness, honesty, responsibility, respect, tolerance of others, fortitude, selfdiscipline, teamwork, and leadership.

Maksud dari kutipan di atas bahwa pendidikan karakter akan menolong orang-orang muda mengerti 
nilai etis seperti kewajaran, kejujuran, tanggungjawab, hormat, toleransi dengan orang lain, kecekatan, disiplin diri, kerjasama sekelompok, dan kepemimpinan yang baik. Pendidikan karakter mengangkat nilai-nilai universal yang dapat diterima oleh latar belakang agama, budaya dan tradisi yang berbeda, tidak sekedar mengangkat teori semata namun juga aplikasinya di masyarakat.

\begin{tabular}{lrr}
\multicolumn{2}{c}{ Pendidikan } & karakter \\
dimaksudkan & sekaligus & sebagai \\
pembentukan & karakter. & Pendidikan
\end{tabular}
karakter itu sendiri merupakan sebuah proses panjang, yaitu proses pembelajaran untuk menanamkan nilainilai luhur, budi pekerti, akhlak mulia yang berakar pada ajaran agama, adat istiadat, dan nilai-nilai keindonesiaan dalam rangka mengembangkan kepribadian peserta didik supaya menjadi manusia yang bermartabat, menjadi warga bangsa yang berkarakter sesuai dengan nilai-nilai luhur bangsa dan agama. Dengan demikian, siswa membutuhkan pendidikan karakter yang akan membentuk karakter positif.

Menurut Brooks dan Gooble (Elmubarok, 2008, p.112) dalam menjalankan pendidikan karakter terdapat tiga elemen yang penting untuk diperhatikan yaitu prinsip, proses, dan praktiknya dalam pembelajaran. Dalam menjalankan prinsip itu, nilai-nilai yang diajarkan harus termanifestasikan dalam kurikulum sehingga semua siswa dalam sekolah paham benar tentang nilai-nilai tersebut dan mampu menerjemahkannya dalam perilaku nyata. Untuk itu diperlukan pendekatan optimal untuk mengajarkan karakter secara efektif yang menurut Brooks dan Gooble harus diterapkan di seluruh sekolah (schoolwide approach). Pendekatan yang sebaiknya dilaksanakan adalah meliputi: (1) Sekolah harus dipandang sebagai suatu lingkungan yang diibaratkan seperti pulau dengan bahasa dan budayanya sendiri. Sekolah juga harus memperluas pendidikan karakter bukan saja kepada guru, staf, dan siswa didik, tetapi juga kepada keluarga/rumah dan masyarakat; (2) Dalam menjalankan kurikulum karakter sebaiknya: (a) pembelajaran tentang nilai-nilai berhubungan dengan sistem sekolah secara keseluruhan; (b) diajarkannya sebagai subyek yang berdiri sendiri (separate-stand alone subject) namun diintegrasikan dalam kurikulum sekolah keseluruhan; (c) seluruh staf menyadari dan mendukung tema nilai yang diajarkan; (3) Penekanan ditempatkan untuk merangsang bagaimana siswa menterjemahkan prinsip nilai ke dalam bentuk perilaku pro sosial.

Mengingat moral adalah sesuatu yang bersifat abstrak maka nilai-nilai kebaikan harus diajarkan pada generasi muda. Oleh sebab itu tema yang sesuai dengan usia anak dalam berpikir konkrit perlu diakomodasi. Cerita-cerita kepahlawanan dan kisah kehidupan yang perlu diteladani baik dari para orang bijak, maupun para pejuang bangsa dan humanisme tetap diperlukan. Bahkan imajinasi anak terhadap kehidupan yang ideal ini (meskipun apa yang dilihatnya dari sekitarnya tidaklah demikian) perlu ditekankan kepada anak agar ia mencintai kebajikan dan terdorong untuk berbuat yang sama. Oleh sebab itu, perlu dipahami benar oleh para pendidik bahwa pendidikan moral dan karakter adalah seperti dua sisi mata uang yang saling melengkapi yang memiliki tujuan mulia dalam membentuk moral manusia, sebab tanpa moral maka manusia seperti dikatakan oleh Wilson (Elmubarok, 2008, p.113) hanyalah seperti "social animal". Untuk itu, tugas para pendidik dan sekolah adalah menjadikan manusia menjadi makhluk baik yang beradab dan berbudi luhur, seperti yang diungkapkan oleh Lickona (1999, p.114):

Moral education is not a new idea. It is in fact, as old as education itself. Down through history, in countries all over 
the world, education has had two great goals: to help young people become smart and to help them become good.

Berdasarkan uraian yang dipaparkan di atas, dapat disimpulkan bahwa pendidikan karakter adalah sebuah proses menumbuh kembangkan nilai-nilai kejujuran, ketaatan, kedisiplinan dan tanggungjawab terhadap organisasi sekolah serta mendewasakan kepribadian seseorang.

Pendidikan karakter penting dan mendesak untuk dilakukan pada saat ini karena hasil pendidikan tidak sesuai dengan tujuan pendidikan, apalagi melihat fenomena di kalangan remaja. Dekadensi moral yang semakin meningkat disebabkan pendidikan tidak menyentuh aspek afektif, sehingga perilaku siswa tidak mencerminkan manusia yang memiliki karakter baik, yang ada hanyalah siswa cerdas tetapi memiliki emosi tumpul, untuk itulah guru perlu mendidik siswa agar memiliki karakter positif. Untuk itulah guru mengupayakan pendidikan karakter agar siswa memiliki karakter positif.

Menurut Lickona (1991, p.53) bahwa seseorang yang hanya memiliki pengetahuan nilai moral itu tidak cukup untuk menjadi manusia berkarakter. Nilai moral harus disertai dengan adanya karakter bermoral. Termasuk dalam karakter ini ada tiga komponen karakter yaitu pengetahuan tentang moral (moral knowing), perasaan tentang moral (moral feeling), dan perbuatan bermoral (moral actions). Hal ini diperlukan agar manusia mampu memahami, merasakan, dan sekaligus mengerjakan nilai-nilai kebajikan

$$
\text { Undang-Undang Nomor } 20 \text { Tahun }
$$

2003 tentang Sistem Pendidikan Nasional (Sisdiknas) Pasal I ayat (1), menyatakan bahwa:

Pendidikan adalah usaha sadar dan terencana untuk mewujudkan suasana belajar dan proses pembelajaran agar peserta didik secara aktif mengembangkan potensi dirinya untuk memiliki kekuatan spiritual keagamaan, pengendalian diri, kepribadian, kecerdasan, akhlak mulia, serta keterampilan yang diperlukan dirinya, masyarakat bangsa dan negara.

Menurut Foester (Koesoema, 2010, p.42), tujuan pendidikan adalah untuk pembentukan karakter yang terwujud dalam kesatuan esensial antara si subjek dengan perilaku dan sikap hidup yang dimilikinya. Karakter merupakan sesuatu yang mengualifikasi seorang pribadi, yang memberikan kesatuan dan kekuatan atas keputusan yang diambilnya. Oleh karena itu, karakter menjadi semacam identitas yang mengatasi pengalaman kontingen yang selalu berubah. Dari kematangan karakter inilah kualitas seorang pribadi diukur. Menurut Zuriah (2008, p.65), tujuan pendidikan karakter yaitu memfasilitasi siswa agar mampu menggunakan pengetahuan, mengkaji danmenginternalisasiserta

mempersonalisasikan nilai, mengembangkan keterampilan sosial yang memungkinkan tumbuh dan berkembangnya akhlak mulia dalam diri siswa serta mewujudkanya dalam perilaku sehari-hari, dalam berbagai konteks sosial budaya yang berbhineka sepanjang hayat. Esensi tujuan pendidikan karakter tersebut perlu dijabarkan dalam pengembangan pembelajaran (instruksional) dan sumber belajar setiap mata pelajaran yang relevan dengan tujuan. Hal tersebut dimaksudkan agar siswa mampu menggunakan pengetahuan, nilai, ketrampilan mata pelajaran itu sebagai wahana yang memungkinkan tumbuh dan berkembangmya serta terwujudnya sikap dan perilaku siswa yang konsisten dan koherensi dengan konsepsi akhlak mulia yang dipersyaratkan bagi manusia Indonesia 
seutuhnya. Selain itu, tujuan tersebut secara instrumental dijabarkan dalam rangka membangun tatanan dan iklim sosial-budaya dunia persekolahan yang berwawasan dan memancarkan akhlak mulia sehingga lingkungan dan kultur sekolah menjadi teladan atau model pendidikan karakter secara utuh.

Sekolah merupakan institusi yang memiliki tugas penting bukan hanya untuk meningkatkan penguasaan informasi dan teknologi dari anak didik, tetapi ia juga bertugas dalam pembentukan kapasitas bertanggungjawab siswa dan kapasitas pengambilan keputusan yang bijak dalam kehidupan, seperti diungkapkan oleh Mann (1837) seperti yang dikutip oleh (Elmubarok, 2008, p.106) yang menyatakan, "the highest and noblest office of education pertains to our moral nature. The common school should teach virtue before knowledge, for knowledge without virtue poses its own dangers". Inti dari pendapat tersebut bahwa sekolah haruslah menjadi penggerak utama dalam pendidikan yang bebas (free public education), dimana pendidikan sebaiknya bersifat universal, tidak memihak (non sectarian), dan bebas. Dengan demikian menurut Mann maupun John Dewey, seorang filsuf pendidikan, tujuan utama pendidikan adalah sebagai penggerak efisiensi sosial, pembentuk kebijakan kewarganegaraan (civic virtue) dan penciptaan manusia berkarakter. Untuk itulah kemudian disusun suatu model baru dalam pendidikan moral yang berujung pada pendidikan karakter agar permasalahan moral dapat diatasi. Brooks dan Goble dalam bukunya The Case for Character Education menyarankan agar sistem pendidikan moral tidak lagi memikirkan tentang nilai-nilai siapa yang akan diajarkan pada siswa di sekolah, akan tetapi perlu dipikirkan nilai-nilai apa yang akan diajarkan pada siswa (what values should we teach?). Sjarkawi (2006, p.39) mengungkapkan bahwa pendidikan karakter bertujuan membina terbentuknya perilaku siswa yang baik bagi setiap orang. Artinya, pendidikan karakter bukan sekadar rnemahami tentang aturan benar dan salah atau mengetahui tentang ketentuan baik dan buruk, tetapi harus benar-benar meningkatkan perilaku moral seseorang. Oleh karena itu, evaluasi keberhasilan harus menggunakan perwujudan perilaku karakter sebagai ukurannya.

Berdasarkan pemaparan di atas, dapat disimpulkan bahwa tujuan utama pendidikan karakter adalah untuk memfasilitasi siswa agar mampu menggunakan pengetahuan, mengkaji dan menginternalisasi serta mempersonalisasi nilai, mengembangkan ketrampilan sosial yang memungkinkan tumbuh dan berkembangnya akhlak mulia dalam diri siswa serta mewujudkannya dalam perilaku seharihari.

Atas dasar pengertian di atas, sekolah sebagai lembaga pendidikan bertanggung jawab untuk meningkatkan kemampuan berpikir dan kecakapan siswa dalam menetapkan suatu keputusan untuk bertindak atau untuk tidak bertindak. Pernyataan tersebut sejalan dengan pendapat Ki Hajar Dewantara mengenai pendidikan, dimana pendidikan berarti daya upaya untuk memajukan pertumbuhan nilai moral (kekuatan batin, karakter), pikiran (intellect) anak antara yang satu dengan yang lainnya agar dapat memajukan kesempurnaan hidup. Oleh karena itu, sekolah sebagai lembaga pendidikan mempunyai beban dan tanggung jawab untuk melaksanakan pendidikan moral dan membantu siswa mengembangkan cara berpikirnya dalam menetapkan keputusan moralitasnya.

Aktualisasi dari upaya dan tujuan pendidikan nasional di atas, di harapkan terimplementasi dalam berbagai model dan bentuk pendidikan di Indonesia. 
Salah satu bentuk yang harus tetap dipertahankan dan dilaksanakan adalah pendidikan agama. Hal ini disebabkan karena pendidikan agama, khususnya Islam merupakan usaha yang lebih khusus ditekankan untuk mengembangkan fitrah keberagamaan dan sumberdaya insani agar mampu memahami, menghayati, dan mengamalkan ajaran-ajaran Islam, yang mengilhami tujuan pendidikan nasional di Indonesia. Salah satu bentuk dan model pendidikan Islam di Indonesia adalah model pendidikan pesantren

Model pendidikan pesantren menarik pula untuk dikaji. Berdasarkan sejarah, model ini merupakan pionir dalam gelanggang pendidikan bangsa Indonesia dengan penanaman nilai didalamnya. Pesantren yang menerapkan sistem berasrama atau pondok amat memungkinkan melakukan pengawasan melekat terhadap para santrinya selama hampir 24 jam.

Nurcholish Masjid mengatakan bahwa dari segi historis, pesantren tidak hanya identik dengan makna keislaman, tetapi juga mengandung makna keaslian Indonesia (indigenous), sehingga dengan sendirinya bernilai posistif dan harus dikembangkan (Masjid, 1997, p.3). Sebagai lembaga pendidikan Islam, pesantren dari sudut historis kultural dapat dikatakan sebagai "training center" yang otomatis menjadi pusat budaya Islam, yang disahkan atau dilembagakan oleh masyarakat, setidaknya oleh masyarakat Islam sendiri yang secara de facto tidak dapat diabaikan oleh pemerintah. Pengakuan dari masyarakat inilah yang menyebabkan pesantren tetap bisa bertahan dari perubahan, karena masyarakat merasa membutuhkan kehadiran pesantren sebagai basis pengembangan keilmuan keagamaan dan pengontrol moral masyarakat beragama.

Pesantren sebagai pranata pendidikan ulama (intelektual muslim) pada umumnya terus menyelenggarakan misinya menyiapkan santri dalam mendalami dan menguasai ilmu pengetahuan agama (tafaqquh fi al-din) dan memotifasi kader ulama dalam misi dan fungsinya debagai warasat al anbiya (penerus para nabi). Hal ini terus dipertahankan agar pesantren tidak tercerabut dari akar utamanya yang telah melembaga selama ratusan tahun. Bahwa kemudian muncul tuntutan modernisasi pesantren, sebagai dampak dari modernisasi pendidikan pada umumnya, tentu hal itu merupakan suatu yang wajar sepanjang menyangkut aspek teknis operasional penyelenggaraan pendidikan. Jadi, modernisasi tidak kemudian membuat pesantren terbawa arus sekularisasi karena ternyata pendidikan sekuler yang sekarang ini menjadi tren, dengan balutan pendidikan modern, tidak mampu menciptakan generasi mandiri.

Dari perspektif pendidikan, pesantren merupakan satu-satunya lembaga kependidikan yang tahan terhadap berbagai gelombang modernisasi (Suwendi, 2004, p.157). Dengan kondisi demikian, menyebabkan pesantren tetap survive sampai hari ini. Nilai-nilai progresif dan inovatif diadopsi sebagai suatu strategi untuk mengejar ketertinggalan dari model pendidikan lain. Dengan demikian, pesantren mampu bersaing dan sekaligus bersanding dengan sistem pendidikan modern (Abasri, 2009, p.286). Yang kemudian perlu dicermati adalah bagaimana kesiapan pesantren menghadapi masyarakat yang global dan tidak hanya mengekor pada kemajuan intelektual dan teknologi. Tidak dapat disangkal bahwa umat Islam saat ini tidak pernah menghasilkan penemuan yang fenomenal dalam mewarnai intelektualitas dunia.

Satu hal yang menarik dari pesantren adalah adanya pendidikan kemandirian, baik dalam kemandirian hidup atau kemandirian menuntut ilmu, 
yang tentunya hal ini akan sangat jarang ditemukan di lembaga pendidikan lainnya. Dengan pembelajaran seperti ini, santri dituntut dan dimotivasi untuk belajar secara mandiri dan tidak hanya menerima begitu saja

Dewasa ini tidak sedikit pesantren di Indonesia telah mengadopsi sistem pendidikan formal seperti yang diselenggarakan pemerintah. Pada umumnya pilihan pendidikan formal yang didirikan di pesantren masih berada pada jalur pendidikan Islam, seperti: Madrasah Ibtidaiyah (MI) yang setara dengan Sekolah Dasar, Madrasah Tsanawiyah (MTs) setara dengan Sekolah Menengah Pertama, dan Madrasah Aliah (MA) yang setara dengan Sekolah Menengah Atas. Namun demikian, ada pula pesantren yang sudah memiliki lembaga pendidikan sistem sekolah, seperti: Sekolah Dasar, Sekolah Menengah Pertama, Sekolah Menengah Atas dan Sekolah Menengah Kejuruan. Beberapa pesantren bahkan sudah membuka perguruan tinggi, baik berbentuk institut agama Islam maupun universitas.

Madrasah Aliyah Pondok

Pesantren Wahid Hasyim Yogyakarta adalah salah satu contoh lembaga pendidikan formal di bawah naungan Pondok Pesantren Wahid Hasyim Yogyakarta yang mengutamakan proses dalam meningkatkan perkembangan siswanya. Kurikulum Madrasah Aliyah Pondok Pesantren Wahid Hasyim Yogyakarta merupakan perpaduan antara kurikulum Kemdikbud, Kemenag dan Pesantren.

Nilai-nilai yang berkembang dalam pesantren diharapkan mampu mendukung penerapan pendidikan karakter pada setiap proses pembelajaran di MA Pondok Pesantern Wahid Hasyim, sejalan dengan penggalakan program character building yang sedang diupayakan oleh pemerintah saat ini. Dalam Kegiatan pembelajaran IPS (Ilmu Pengetahuan Sosial) merupakan salah satu mata pelajaran yang strategis untuk menanamkan nilai-nilai moral kepada peserta didik. Kirschenbaum menegaskan, bahwa tujuan akhir dari studi Ilmu Pengetahuan Sosial (IPS) adalah diarahkan untuk tercapainya tujuan pendidikan moral. John Dewey juga mengemukakan bahwa proses dan tujuan akhir studi-studi sosial harus bermuara pada terwujudnya moral dalam mengembangkan kepribadian manusia (Sjarkawi, 2008, p.42).

Pendidikan IPS sebagai bagian dari pendidikan secara umum memiliki peran penting dalam peningkatan mutu pendidikan. Secara khusus pendidikan IPS turut serta berperan dalam menghasilkan peserta didik yang berkualitas, yaitu manusia yang mampu berfikir kritis, kreatif, logis, dan berinisiatif dalam menanggapi gejala dan masalah sosial yang berkembang dalam masyarakat yang diakibatkan oleh perkembangan teknologi di era global. Bila dilihat dari fungsi dan tujuan kurikulum IPS jelas bahwa pendidikan IPS sangat penting bagi anak-anak dalam kehidupannya baik sebagai warga negara, warga masyarakat, maupun sebagai individu. Oleh karena itu, pembelajaran IPS hendaknya mampu mengembangkan berbagai dimensi, baik yang menyangkut pengetahuan, sikap, maupun ketrampilan. IPS berfungsi mengembangkan pengetahuan, sikap, dan ketrampilan dasar untuk memahami kenyataan sosial yang dihadapi siswa dalam kehidupan sehari-harinya serta mampu mengembangkan ketrampilan dasar yang berguna bagi dirinya (Isjoni, 2007, p.54).

Mempelajari IPS pada dasarnya adalah mengembangkan pengetahuan, nilai, sikap, serta ketrampilan sosial siswa untuk dapat menelaah kehidupan sosial yang dihadapi sehari-hari dengan tujuan agar siswa mampu 
mengembangkan pengetahuan, nilai, dan sikap, serta ketrampilan sosial yang berguna bagi dirinya. Pendidikan IPS mempunyai peranan untuk (a) sosialisasi, yaitu membantu siswa menjadi anggota masyarakat yang berguna dan efektif; (b) pengambilan keputusan, yaitu membantu siswa mengembangkan ketrampilan berfikir dan ketrampilan akademis; (c) sikap dan nilai, yaitu membantu siswa menandai, mengembangkan dan menilai sendiri dalam hubungannya dengan kehidupan masyarakat sekitarnya; dan (d) kewarganegaraan, yaitu membantu siswa menjadi warga negara yang baik (Isjoni, 2007, p.34)

Dengan demikian, pendidikan IPS tidak dapat menghindari tugas pengembangan moral dan etika. Dalam pembelajaran IPS, salah satu hal yang penting untuk diperhatikan adalah metode pembelajaran. Selama ini metode pembelajaran IPS yang berkembang di sekolah pada umumnya adalah metode fungsional. Adapun kriteria dari metode fungsional tersebut, yaitu: (1) memiliki standar objektivitas yang kaku, (2) mengacu pada pengembangan kognitif, dan (3) guru juga lebih banyak mengejar target yang berorientasi pada nilai ujian akhir sehingga berakibat siswa lebih suka menghafal materi daripada memahami esensi dari ilmu yang disampaikan oleh guru di kelas (http://writingsdy.wordpress.com/2011/ 12/01) Oleh sebab itu, Kock (1994, p.101) menyatakan bahwa guru yang baik bukan mengajar dengan satu metode saja, ia mampu memakai cara mengajar yang paling cocok untuk mencapai tujuan pengajaran tertentu.

Sebagai salah satu lembaga pendidikan yang memadukan antara pondok pesantren dan pendidikan formal, MA Pondok Pesantren Wahid Hasyim Yogyakarta dipilih sebagai objek dalam kajian ini, hal ini didasarkan pada keberlangsungan sistem yang ada di madrasah tersebut. Adanya seperangkat nilai-nilai pesantren belum mendukung pencapaian yang optimal pada keberlangsungan implementasi pendidikan karakter di MA Pondok Pesantren Wahid Hasyim Yogyakarta termasuk dalam proses pembelajaran IPS. Pendidikan karakter dalam pembelajaran IPS tampaknya masih belum diterapkan secara maksimal. Belum semua guru IPS yang ada di MA Pondok Pesantren Wahid Hasyim Yogyakarta memahami adanya hubungan yang penting antara pesantren dengan sekolah, sehingga belum didapatkan sinergi yang baik antara pendidikan karakter yang diterapkan pemerintah termasuk implementasinya juga dalam pembelajaran IPS dengan pendidikan karakter yang sudah berlangsung di pesantren. Adanya fenomena tersebut, telah menarik peneliti untuk melakukan penelitian di MA Pondok Pesantren Wahid Hasyim Yogyakarta. Penelitian ini memfokuskan pada proses implementasi pendidikan karakter dalam pembelajaran IPS yang ada di MA Pondok Pesantren Wahid Hasyim Yogyakarta.

Terkait dengan hal itu penelitian ini bertujuan untuk (1) program pendidikan karakter di MA Pondok Pesantren Wahid Hasyim Yogyakarta, (2) implementasi pendidikan karakter dalam pembelajaran IPS di MA Pondok Pesantren Wahid Hasyim Yogyakarta, (3) metode yang digunakan guru untuk mengimplementasikan pendidikan karakter dalam pembelajaran IPS di MA Pondok Pesantren Wahid Hasyim Yogyakarta, (4) faktor-faktor yang menjadi penghambat dan pendukung implementasi pendidikan karakter di MA Pondok Pesantren Wahid Hasyim Yogyakarta.

\section{METODE}

Penelitian ini termasuk jenis penelitian kualitatif naturalistik yaitu menafsirkan fenomena yang ditemui di 
lapangan, dan tidak memanipulasi dalam pengolahannya. Penelitian ini dilaksanakan di MA Pondok Pesantren Wahid Hasyim Yogyakarta pada bulan Desember 2011 hingga April 2012. Penelitian ini menekankan perilaku individu-individu sebagai warga sekolah di MA Pondok Pesantren Wahid Hasyim Yogyakarta. Subjek penelitian ini adalah siswa, guru, kepala sekolah, pengasuh dan karyawan. Penentuan sampel dilakukan dengan menggunakan purposive sampling dan snowball sampling. Instrumen pengumpulan data penelitian ini adalah peneliti sendiri. Sebagaimana dikatakan Sugiyono (2009, p.307) bahwa dalam penelitian kualitatif yang menjadi instrumen utama adalah peneliti sendiri. Teknik pengumpulan data yang digunakan dalam penelitian ini adalah: observasi, wawancara, dokumentasi, dan catatan lapangan.

Instrumen pengumpulan data yang digunakan tiga pedoman dalam penelitian ini yaitu: (1) pedoman observasi dan catatan lapangan digunakan sebagai alat pengumpulan data, setelah dikumpulkan kemudian melakukan analisis lebih lanjut, (2) pedoman wawancara terstruktur dan pedoman wawancara tidak terstruktur, ini khusus dipergunakan untuk mengumpulkan data yang diperoleh dari hasil wawancara yang dilakukan peneliti saat melakukan pengumpulan data di lapangan, (3) dokumentasi antara lain photo, rekaman, dan alat tulis.

Teknik analisis data yang digunakan dalam penelitian ini meliputi: (1) analisis sebelum di lapangan meliputi: analisis data yang diperoleh dari studi pendahuluan, atau data sekunder yang akan dipergunakan untuk menentukan fokus penelitian meskipun fokus ini sifatnya masih sementara (2) analisis selama di lapangan yaitu analisis yang dilakukan saat pengumpulan data berlangsung dan setelah pengumpulan data dalam waktu tertentu. Untuk menganalisis data selama di lapangan peneliti mengunakan model analisis interaktif, (3) verifikasi data dan menarik kesimpulan. Kesimpulan awal yang dikemukakan masih bersifat sementara, yang kemudian disempurnakan berdasarkan perolehan data yang lebih lengkap.

\section{HASIL DAN PEMBAHASAN}

\begin{tabular}{lcr}
\multicolumn{2}{c}{ Program } & merupakan langkah \\
pertama yang & menyangkut & aspek \\
perencanaan. & Di dalam & tahap
\end{tabular} perencanaan ini diuraikan garis-garis besar kegiatan sekolah yang terkait dengan pembinaan Selanjutnya perencana program kerja itu di implementasikan dalam bentuk kegiatankegiatan sekolah.

Menurut Arthur (2003, p.114) dalam menelaah program pendidikan karakter, ada enam metode yaitu: (1) instruksi nilai-nilai dan kebaikan dasar, (2) kode etik perilaku ditegakkan dan dilaksanakan,(3) memberitahukan sejarah pelajaran moral, (4) memberikan model (teladan) sifat-sifat dan nilai yang diinginkan, (5) memegang teguh para tauladan moral yang ada dalam sejarah, literatur, agama, dan memuji sifat-sifat mereka, dan (6) menyediakan kesempatan yang luas di sekolah dan masyarakat (proyek jasa), melalui muridmurid, dapat dilatih sifat-sifat yang baik dan mengajarkan nilai-nilai luhur.

MA Pondok Pesantren Wahid Hasyim menyelenggarakan program pendidikan dengan menggunakan sistem paket yang telah disesuaikan dengan situasi dan kondisi sekolah serta lingkungan masyarakat sekitar. Sistem paket adalah program penyelenggaraan pendidikan yang wajib diikuti seluruh siswa yang ditetapkan pada setiap kelas sesuai dengan struktur kurikulum yang berlaku di sekolah itu. Setiap mata pelajaran pada sistem paket dinyatakan dalam satuan jam pertemuan. Pendidikan karakter dilaksanakan oleh 
guru melalui pembelajaran di kelas, sesuai dengan mata pelajaran masingmasing. Oleh karena itu, semua guru diharuskan memberikan pembinaan karakter siswa. Tetapi berdasarkan hasil pengamatan peneliti, bahwa pembinaan karakter hanya diajarkan pada beberapa mata pelajaran seperti mata pelajaran Agama, Bahasa Inggris, seni dan budaya, IPS, dan PKn. Pada prinsipnya program kerja di MA Pondok Pesantren Wahid Hasyim dibuat dengan memperhatikan visi, misi sekolah, dalam bentuk program pembinaan karakter Islami.

Selain pembentukan karakter di atas, dalam kegiatan ekstrakurikuler, guru atupun pembina asrama juga mengupayakan tes baca al-Qur'an pada saat menerima siswa baru, kegiatankegiatan asrama di pesantren (guru dan siswa diwajibkan mengikuti sebagai bentuk pendampingan), memberikan bimbingan khusus seni beladiri (Pagar Nusa), Taekwondo pada siswa dengan mendatangkan pelatih yang profesional, tadarus al-Qur'an dan program hafalan (tahfidzul Qur'an), forum organisai santri Wahid Hasyim (OSWAH) berkerja sama dengan OSIS melaksanakan kajian rutin tentang Islam, menjalankan amalan ibadah sehari-hari (amalanyaumiah), serta dapatmempertanggung jawabkan seluruh aspek kegiatan sehari-hari nya.

Membentuk karakter melalui membiasakan disiplin, kerja sama, tolong-menolong, menghargai orang tua dan guru atau pembina dan staf-staf lainnya, merupakan teladan yang baik bagi siswa. Kalau guru tidak melakukan sendiri, akan sulit membentuk karakter siswa, terutama pada tingkat siswa di masa remaja, karena siswa-siswa usia SMA/MA sedang pada masa peralihan fase perkembangan menuju dewasa, masih labil, sangat cepat terpengaruh oleh hal negatif. Kalau hal ini tidak diterapkan dengan baik, tanpa diberikan contoh oleh guru, maka pendidikan karakter akan tidak mendapat hasil yang maksimal.

Hasil pendidikan karakter sangat tergantung pada pembinaan keluarga dan lingkungan sekitarnya, seperti halnya disampaikan Montessori (2008, pp.349-350) bahwa semua persoalan ini dapat dipecahkan jika kita memahami rangkaian aktivitas konstruktif yang semestinya dilalui dengan baik dan secara alami oleh setiap anak. Sudah banyak pengalaman menunjukkan bahwa cacat karakter anak merupakan akibat dari perlakuan sehari-hari orang dewasa yang tidak baik kepada anak. Jika anak-anak ditelantarkan di rumah, maka pikiran mereka pun kosong karena tidak memiliki kesempatan untuk mengisinya. Oleh karena itu, peran warga sekolah untuk membentuk karakter siswa sejak dini.

Pembentukan karakter siswa di MA Pondok Pesantren Wahid Hasyim melalui pembiasaan kultur sehari-hari. Setiap masuk sekolah siswa selalu bersalama dengan guru dan pembina. Guru ataupun pembina mengajarkan dan memberi contoh langsung kepada siswa tata cara shalat (khususnya mata pelajaran agama), siswa terlambat dipanggil dan dinasihati, begitu juga jika siswa terlambat datang pada waktu upacara tiga kali berturut-turut dipanggil dan dicubit telinganya. Guru selalu mengontrol siswa yang pada waktu waktu shalat berjamaah tidak mengikuti, dan yang dalam waktu istirahatnya melampaui batas waktu, serta yang nakal/jahat kepada sesama teman. Guru memanggil siswa tersebut untuk diberikan hukuman atau berupa nasihat.

Menurut hasil analisis Arthur (2003, p.22) bahwa dalam pembentukan karakter anak akan lebih baik bila selalu diberi perhatian dan nasihat, karena membentuk karakter siswa adalah membiasakan berlaku baik pada anakanak, bersama-sama dengan menanamkan sifat-sifat yang baik. Dia 
tidak percaya bahwa para guru dapat memberi perhatian yang memadai kepada siswanya dalam pembentukan karakter. Pada sekolah-sekolah tertentu (independen) dapat terus menerus memberikan perhatian terhadap pembentukan karakter, dengan menekankan ketertarikan pada sekolah swasta yang pendidikan karakternya sudah berhasil.

Pendidikan karakter diwujudkan dalam bentuk pengembangan kepercayaan diri, kualitas kepemimpinan, kesetiaan pada pemimpin, dan keterampilan sosial. Pendidik di sekolah mempunyai kewajiban untuk membantu membangun karakter siswa, karena di sekolah siswa terpisah dari orang tuanya, maka para pendidik di sekolah yang bertanggung jawab untuk mendidik siswa dengan baik. Pengaruh-pengaruh dari luar yang tidak ada penanggungjawabnya dapat berakibat fatal.

Pelaksanaan kegiatan di sekolah sehari-hari, seperti tadarus dan program hafalan Qur'an (Tahfidzul Qur'an), shalat 5 waktu berjamaah, kepramukaan, dan bela diri, muhadharah, kajian kitab pesantren (kitab kuning) merupakan ajang pendidikan karakter yang hanya terjadi di sekolah-sekolah yang mengadopsi pendidikan formal dan pesantren. Hal ini dapat dijelaskan sebagai berikut:

\section{Tadarus al-Qur'an dan Tahfidz al-Qur'an}

Program ini dilaksanakan setiap hari yaitu, pada waktu setelah shalat maghrib yang bertempat di asrama, dan sebelum masuk jam pertama pada pukul 06.30 yang bertempat di ruang kelas. Kegiatan ini selalu dipantau oleh guru yang mengajar muatan lokal secara serempak di masing-masing kelas. Peneliti mengamati disetiap kelas maupun ketika di asrama semua anakanak membaca al-Qur'an dimulai dengan surat al-Fatihah dan surat berikutnya yang ditentukan oleh guru pembimbing. Sesekali guru menghentikan anak dalam membaca al-Qur'an karena ada yang salah untuk dibetulkan. Guru dan pembina menunjukkan kesalahannya, kemudian memberikan contoh bacaan yang benar.

MA Pondok Pesantren Wahid Hasyim merupakan sekolah yang bercirikan Islam berbasis pesantren, maka para siswa dituntut untuk memiliki pemahaman Islam yang lebih mendalam, dan lebih taat dalam menjalankan ibadah. Oleh karena itu, tadarus dan tahfidz al -Qur'an ini ditetapkan sebagai kurikulum muatan lokal, dan kemampuan anak di bidang ini menjadi bagian dari kompetensi dasar pada mata pelajaran keislaman. Baca tulis al-Qur'an dan hafalan Qur'an merupakan mata pelajaran wajib bagi siswa di MA Pondok Pesantren Wahid Hasyim.

Sekolah mengangap penting kegiatan tersebut karena disamping baca tulis al-Qur'an, juga dibiasakan menghafal ayat-ayat al- Qur'an, kegiatan ini dimaksudkan untuk menunjukkan kepada orang tua/wali murid terhadap putra-putrinya di MA Pondok Pesantren Wahid Hasyim sebagai sekolah yang bercirikan dan berbasis pesantren. Sedangkan pentingnya kegiatan ini untuk memperkenalkan kepada siswa tentang isi al-Qur'an dan lebih-lebihnya untuk tujuan agar mereka dapat menjadikan alQur'an sebagai pedoman dalam bertingkah laku.

\section{Shalat Berjamaah}

Shalat berjamaah di MA Pondok Pesantren Wahid Hasyim dilaksanakan setiap hari pada waktu jam-jam sholat yang telah ditentukan, Untuk shalat Subuh, Ashar, Maghrib, Isya' menjadi program asrama sedangkan untuk Shalat Dhuhur berjamaah pelaksanaan bergantian antara siswa laki-laki dan perempuan di Masjid pada jam istirahat kedua. Membaca al-Qur'an dan 
menjalankan ibadah shalat berjamaah di sekolah, merupakan sarana untuk melatih dan membiasakan para siswa, agar kelak menjadi orang yang shaleh, seperti dikemukakan Nata (2008, p.219), orang yang sering membaca al-Qur'an adalah orang yang membuktikan keimanannya dalam bentuk amal saleh, bersikap jujur, amanah, berbuat adil, kepedulian sosial, dan sebagianya. Hal ini juga disebutkan dalam al-Qur'an surat Al-Baqrah, 2, p.183, yaitu perintah shalat agar manusia semakin menyadari keagungan Tuhan, timbul rasa tunduk, serta menjauhi perbuatan yang keji dan munkar.

\section{Kegiatan Kepramukaan}

Gerakan Pramuka di MA Pondok Pesantren Wahid Hasyim adalah gerakan pramuka pada umumnya tetapi dipadukan dengan azas Islamiyah. Dalam menunaikan tugas pokoknya selalu berusaha untuk meningkatkan mutu dan mencari jalan yang praktis serta menyesuaikan keadaan di masyarakat pada umumnya dan anggota gerakan pramuka khususnya. Kegiatan Pramuka MA Pondok Pesantren Wahid Hasyim dilaksanakan dua minggu sekali di lingkungan sekolah, pada hari Sabtu jam 16.00 WIB. Kegiatan ini bersifat ekstrakurikuler, tetapi wajib bagi seluruh siswa kelas X dan XI. Dengan kegiatan pramuka nilai pendidikan karakter yang hendak dicapai yaitu dengan siswa dilatih hidup sederhana (bersahaja), disiplin, kerjasama dan mandiri dan mampu mengatasi permasalahan dalam kehidupan sehari-hari dan suka menolong orang lain. Di dalamnya digelar berbagai lomba untuk meningkatkan kreativitas dan menumbuhkan nilai-nilai luhur yang menjadi tujuan gerakan pramuka, yaitu gotong-royong, tolong-menolong, bekerja sama, dan disiplin. Dihilat dari aspek prestasi baik ditingkat kecamatan sampai di tingkat provinsi, MA Pondok
Pesantren Wahid Hasyim dapat meraih piala kejuaraan dari lomba tingkat kwartir ranting dan kwartir cabang. Hal ini membuktikan bahwa kegiatan pramuka di MA Pondok Pesantren Wahid Hasyim sudah berprestasi dan mampu mengangkat citra baik sekolah.

\section{Pagar Nusa}

Pagar Nusa adalah nama perguruan cabang olahraga beladiri di kalangan warga NU, dan menjadi anggota Ikatan Pencak Silat Indonesia (IPSI). Pagar Nusa termasuk dalam 10 Perguruan Historis IPSI, yaitu perguruan yang menunjang tumbuh dan berkembangnya IPSI sebagai organisasi. IPSI Pagar Nusa berdiri pada 31 September 1985 sebagai gabungan dari beberapa pencak silat yang ada di bawah organisasi Nahdlatul Ulama. (sumber. http://pagarnusadaruttaqwa.wordpress. com

Implementasi Pendidikan Karakter dalam Pembelajaran IPS

Kurikulum MA Wahid Hasyim sangat mendukung pendidikan karakter, terutama mata pelajaran IPS. Mata pelajaran tersebut dimaksudkan untuk membentuk siswa menjadi warga negara yang baik, manusia yang beriman dan bertaqwa kepada Allah SWT, yang memiliki pengetahuan, keterampilan dan kepedulian sosial yang berguna bagi dirinya sendiri, masyarakat dan negara.

Kurikulum tingkat satuan pendidikan (KTSP) MA Pondok Pesantren Wahid Hasyim dikembangkan oleh sekolah dan komite sekolah dengan berpedoman pada standar kompetensi lulusan (SKL) dan standar isi (SI) serta panduan penyusunan kurikulum tingkat satuan pendidikan yang dibuat oleh BSNP. IPS pada jenjang menengah keatas diberikan secara tersendiri dalam mata pelajaran ekonomi, sosiologi, geografi dan sejarah. Pelajaran IPS materinya sangat luas, sehingga guru dituntut untuk berusaha mencari berbagai macam 
sumber. Hasil pengamatan terhadap proses pembelajaran IPS, yang materinya Geografi, Sejarah, Ekonomi, dan Sosiologi, diketahui bahwa penguasaan materi oleh guru belum memadai karena guru-guru yang aktif saat ini ada beberapa guru yang berlatar belakang disiplin ilmu bukan pada bidang yang diajarkannya.

Berdasarkan pengamatan peneliti pada pemebelajaran IPS, setiap guru masuk di kelas selalu mengingatkan siswa untuk berbuat baik, memberi salam, membaca surat al-Fatihah, al-'Asri, tolong-menolong sesama teman yang sakit, mengajarkan kejujuran, serta berpakaian yang sopan. Pendidikan karakter di dalam pembelajaran dilakukan oleh guru sejak menyusun rencana persiapan pembelajaran (RPP). Di dalam RPP secara eksplisit dicantumkan nilai-nilai yang akan diberikan kepada siswa. Keberhasilan proses pembelajaran di kelas sangat ditentukan oleh penguasaan materi pelajaran, dan kemampuan guru dalam mengajar, sehingga siswa mampu memahami apa yang disampaikan oleh guru.

Peneliti melihat pembelajaran di kelas pada umumnya memakai metode ceramah dan metode pembiasaan, sedangkan aktivitas praktik jarang digunakan. Metode pembiasaan mengarahkan kepada upaya untuk memudahkan pemahaman karakter pada siswa. Metode pembiasaan ini berperan sebagai latihan yang terus menerus dilakukan siswa sehingga akan lebih terbiasa dalam pembentukan karakternya, misalnya dalam pelajaran guru membiasakan membuka dengan bacaan surat Al-Fatihah dan membiasakan masuk di kelas dengan memberi salam, serta datang tepat waktu. Melalui pembiasaan ini, siswa menjadi lebih baik dalam kehidupan sehari-hari.
Pendidikan karakter dilaksanakan oleh guru melalui pembelajaran di kelas, sesuai dengan mata pelajaran masingmasing. Oleh karena itu, semua guru diharuskan memberikan pembinaan karakter siswa. Tetapi berdasarkan hasil pengamatan peneliti, bahwa pembinaan karakter hanya diajarkan pada beberapa mata pelajaran seperti mata pelajaran.

Berdasarkan pengamatan peneliti pada pemebelajaran IPS, setiap guru masuk di kelas selalu mengingatkan siswa untuk berbuat baik, memberi salam, membaca surat al-Fatihah, al-'Asri, tolong-menolong sesama teman yang sakit, mengajarkan kejujuran, serta berpakaian yang sopan.

Pendidikan karakter di dalam pembelajaran dilakukan sejak menyusun rencana persiapan pembelajaran (RPP). Di dalam RPP secara eksplisit dicantumkan nilai-nilai yang akan diberikan kepada siswa. Keberhasilan proses pembelajaran di kelas sangat ditentukan oleh penguasaan materi pelajaran, dan kemampuan guru dalam mengajar, sehingga siswa mampu memahami apa yang disampaikan oleh guru.

Dalam pelaksanaan pembelajaran ada tiga tahap kegiatan pokok yang harus diperhatikan pada guru yaitu pendahuluan, kegiatan pembelajaran inti, dan penutup yang terdiri atas penilaian dan tindak lanjut. Namun peneliti mengamati di lapangan menunjukkan bahwa tidak semua guru IPS melaksanakan ketiga tahap tersebut.

Peneliti melihat pembelajaran di kelas pada umumnya memakai metode ceramah dan metode pembiasaan, sedangkan aktivitas praktik jarang digunakan. Metode pembiasaan mengarahkan kepada upaya untuk memudahkan pemahaman karakter pada siswa. Metode pembiasaan ini berperan sebagai latihan yang terus menerus dilakukan siswa sehingga akan lebih terbiasa dalam pembentukan 
karakternya, misalnya dalam pelajaran guru membiasakan membuka dengan bacaan surat Al-Fatihah dan membiasakan masuk di kelas dengan memberi salam, serta datang tepat waktu. Melalui pembiasaan ini, siswa menjadi lebih baik dalam kehidupan sehari-hari. Selain proses pembiasaan, hendaknya juga diupayakan ada partisipasi guru untuk pengembangan pendidikan karakter dalam proses pembelajaran. Beberapa bentuk partisipasi guru antara lain: (1) Partisipasi guru di sekolah dapat dilihat pada upaya mereka untuk selalu mengkaji dan memahami pendidikan karakter secara benar. Contohnya, ketika peneliti berada di sekolah guru-guru selalu bertanya dan berdiskusi dengan peneliti tentang metode penerapan pendidikan karakter di kelas. Upaya kongkrit guru-guru IPS diantaranya dengan melibatkan diri dalam acara pengajian-pengajian, tadarusan, mengikuti diklat-diklat atau seminar yang dapat menambah wawasan dalam pendidikan karakter. Usaha yang dilakukan guru ini mempunyai tujuan agar tidak terjadi kesalahan dalam menanamkan pengertian maupun pendidikan karakter kepada siswa. Disamping itu, dengan dilakukannya pengajian rutin guru-guru tiap bulan puasa dan arisan tiap 1 bulan sekali yang diisi ceramah keagamaan untuk menambah wawasan guru akan nilainilai keagamaan dengan harapan diaplikasikan juga dalam kegiatan pembelajaran. (2) Partisipasi guru dalam pendidikan karakter di sekolah juga dapat dilihat pada upaya guru memberikan penanaman konsep tentang karakter. Penanaman konsep tentang karakter pada awal pelajaran atau sebelum guru memulai pelajaran diharuskan membaca surat al-Fatihah, doa belajar, dan membaca surat al-'Asri setelah selesai pelajaran, kemudian guru memberikan pesan karakter yang baik yang harus dilaksanakan oleh siswa, atau berupa nasihat, contohnya jangan lupa shalat, membantu orang tua bekerja ketika di rumah, berjabat tangan dan mengucapkan salam, setelah sampai di sekolah hendaknya bersalaman kepada guru, teman, maupun tamu yang berkunjung ke sekolah dan lain-lain. Berdasarkan pengamatan peneliti di kelas, dijumpai bahwa pesan-pesan yang sama juga diberikan pada hari berikutnya tetapi tidak semua mata pelajaran. (3) Partisipasi guru dalam pendidikan karakter di sekolah juga dapat dilihat pada upaya guru dalam pembelajaran, yaitu bersalaman kepada sesama teman guru, karena kebanyakan siswa meniru sikap dan perilaku guru. Bagi siswa, guru merupakan figur utama di sekolah. Guru di MA Pondok Pesantren Wahid Hasyim diharapkan mempunyai keperibadian yang baik sehingga mereka dapat dijadikan panutan oleh siswa baik ketika berada di sekolah, di lingkungan masyarakat, dan di rumah. (4) Partisipasi guru dalam pendidikan karakter melalui pembelajaran di kelas juga dapat dilihat dari pemantauan dan pemeriksaan pekerjaan rumah, tugas kelompok, dan mengawasi kegiatan siswa di dalam kelas. Melalui hal ini, guru menunjukan tanggungjawab dan perhatiannya yang tinggi terhadap siswa. Partisipasi guru dalam pendidikan karakter melalui pembelajaran di kelas juga dapat dilihat pada pengisian presensi. Salah satu perangkat pembelajaran yaitu buku nilai, tugas guru menilai prestasi akademik siswa dan juga kinerjanya. Pengisian buku tersebut, merupakan laporan guru mengenai perkembangan karakter siswa selama belajar mengajar di kelas.

Metode Pembelajaran IPS

Hasil pengamatan peneliti bahwa proses pembelajaran masih menggunakan metode yang monoton, yaitu metode ceramah. Metode ceramah bersifat teacher centered, siswa hanya 
mendengarkan, kurang beraktivitas, sehingga timbul kejenuhan. Semua guru IPS di MA Pondok Pesantren Wahid Hasyim menggunakan metode ini, dengan sesekali diselingi tanya-jawab, yaitu selesai guru memberikan materi, siswa dipersilahkan bertanya. Namun pada umumnya siswa terdiam, tidak tahu apa yang harus ditanyakan. Sebagai metode tambahan, biasanya guru memberi pekerjaan rumah, kemudian hasilnya didiskusikan di dalam kelas pada pertemuan berikutnya.

Respon Siswa Terhadap Pembelajaran IPS

Respon siswa terhadap proses pembelajaran IPS di dalam kelas merupakan salah satu indikator keberhasilan guru dalam melaksanakan proses pembelajaran. Hasil pengamatan peneliti bahwa respon siswa terhadap proses pembelajaran antara lain tidak memperhatikan ketika guru menjelaskan materi pelajaran, sebagian siswa mainmain, dua-tiga siswa bercanda, dan sebagian siswa yang duduk pada bagian depan responnya positif (memperhatikan) terhadap penjelasan guru, dan memperhatikan temannya yang sedang menyampaikan pertanyaan, serta jawaban dari guru.

Respon siswa terhadap proses pembelajaran dipengaruhi oleh anekaragam aspek yang ada di kelas (Winfred, 2010, p.3). Proses pembelajaran yang multi metode, multi media, multi aspek secara terintegrasi menimbulkan respon yang positif. Respon yang positif ini merupakan salah satu indikator keberhasilan guru dalam mendidik karakter siswa. Untuk sampai kepada respon positif, guru harus merancang pembelajarannya dengan serius, dengan memperhatikan prinsip pembelajaran terintegrasi, dan multi metode, multi media, multi aspek sebagai konsekuensinya. Kenyataan ini masih sulit untuk ditemukan di MA Pondok Pesantren Wahid Hasyim.

Hasil pengamatan peneliti di kelas siswa yang aktif bertanya hanya satu atau dua orang, sama dengan di kelas. Hal ini terjadi karena proses pembelajaran IPS sebagian besar diisi dengan kegiatan mencatat materi yang disampaikan guru, sehingga jarang siswa yang bertanya, bahkan untuk menjawab pertanyaan guru pun menunggu ditunjuk.

Secara umum respon siswa dalam proses pembelajaran IPS di kelas adalah: (1) sopan terhadap guru, (2) semua siswa mengucapkan salam ketika guru masuk kelas, (3) memakai pakaian rapi sesuai dengan aturan sekolah, tetapi (4) responnya negatif atau pasif dalam proses pembelajaran.

Faktor Pendukung dan Penghambat Implemen-tasi Pendidikan Karakter

\section{Faktor Pendukung}

Faktor pendukung pelaksanaan pendidikan karakter di MA Pondok Pesantren Wahid Hasyim, terdiri atas faktor internal dan eksternal. Faktor internal yaitu: (1) peraturan tata tertib dan kultur serta nilai-nilai kepesantrenan (2) dukungan dan kerja sama yang baik antara warga sekolah, dengan siswa dan (3) dukungan orang tua murid. Sedangkan faktor eksternalnya yaitu kerjasama pihak sekolah dengan masyakarat. Selain itu MA Pondok Pesantren Wahid Hasyim letaknya sangat strategis yaitu di ujung kota. Oleh karena itu sekolah ini ditunjuk sebagai Sekolah Binaan Penyiaran Televisi Edukasi dalam hal membantu pembinaan pembelajaran di kelas. Inilah bentuk kerja sama sekolah dengan masyarakat dalam mendukung pendidikan karakter. Selain itu, dukungan Yayasan PP. Wahid Hasyim memberikan apresiasi positif terhadap pengembangan pendidikan karakter di sekolah ini. 


\section{Faktor Penghambat}

Faktor-faktor yang menghambat implementasi pendidikan karakter di MA Pondok Pesantren Wahid Hasyim dapat diidentifikasi sebagai berikut:

\section{a) Sarana dan Prasarana}

MA Pondok Pesantren Wahid Hasyim masih memiliki sejumlah permasalahan diantaranya masalah sarana dan prasarana yang belum lengkap yaitu ruang multimedia, dan perpustakaan sekolah yang belum representatif. Begitu pula perangkat komputer yang masih kurang dalam menunjang kegiatan belajar pada mata pelajaran IPS, peralatan-peralatan lain memang ada tetapi beberapa peralatan yang sudah rusak, ruang belajar di antaranya perlu diperbaiki. Sekolah memiliki fasilitas seperti mushola asrama yang masih sederhana dan ruang belajar juga masih terbatas. Sebagai simpulan bahwa sarana dan prasarana MA Pondok Pesantren Wahid Hasyim belum cukup.

b) Dana dan Pembiayaan

Selama ini dana yang diperlukan untuk pengembangan sarana dan prasaran seperti tempat pengajian dan pendidikan life skills masih ditanggung oleh sekolah walaupun ada bantuan dana dari pemerintah tetapi jumlahnya sangat kecil. Minimnya dana operasional secara tidak langsung berakibat pada keterlaksanaan program pendidikan karakter tidak optimal, demikian pula kelancaran proses penyelenggaraan pendidikan di sekolah juga terhambat.

c) Program

Dibutuhkan waktu yang cukup lama untuk dapat melihat hasil dari program pendidikan karakter. Begitu juga dalam proses pembelajaran baik di kelas maupun di luar kelas karena alokasi waktu yang ditentukan dirasa masih kurang khususnya pelajaran IPS.
Akan tetapi kecil kemungkinan untuk menambah aloksi waktu yang ada sehingga diperlukan kreativitas dan kemampuan melakukan inovasi terhadap metode pembelajaran. Metode mengajar sebagian besar guru yang masih kurang kreatif dan inovatif. Demikian pula pelaksanaan pelajaran yang berhubungan dengan karakter masih rendah, artinya belum semua mata pelajaran IPS mengimplementasikan pendidikan karakter.

\section{d. Pembinaan Karakter}

Belum semua guru IPS atau karyawan mampu menjadi contoh karakter siswa, dan bahkan guru kurang aktif membantu kegiatan pembinaan karakter siswa dalam kegiatan ekstrakurikuler dan intrakurikuler. Beberapa di antaranya bahkan bersikap kontra produktif dengan tidak memberikan contoh yang semestinya, seperti: tidak mengikuti shalat berjamaah di masjid dan tidak mengucapkan salam dan bersalaman, dan lain-lain. Meskipun persentasinya kecil, namun hal ini dapat menghambat pendidikan karakter yang dilakukan oleh teman sejawatnya. Latar belakang karakter siswa sangat bervariasi, maka dibutuhkan perhatian dan kemampuan guru yang bervariasi pula. Budaya malas pada sebagian guru juga sangat menghambat implementasi pendidikan karakter di sekolah. Hasil pengamatan di kelas menunjukkan bahwa guru yang sedang mengajar sama sekali tidak melakukan pembinaan karakter. Guru tersebut mengajarkan materi pelajaran secara monoton dan tidak mengintegrasikan nilai-nilai karakter dalam mata pelajaran. Pengaruh media elektronik khususnya televesi juga dapat menghambat pendidikan karakter siswa..

\section{SIMPULAN}

Implementasi pendidikan karakter dalam pembelajaran IPS di MA 
Pondok Pesantren Wahid Hasyim dapat di simpulkan sebagai berikut.

Pendidikan karakter dilaksanakan melalui kegiatan intrakurikuler dan ekstrakuriker. Pendidikan karakter dalam kegiatan intrakurikuler dimplementasikan dalam setiap mata pelajaran termasuk dalam pembelajaran IPS. Pendidikan karakter dalam kegiatan ekstrakurikuler dilaksanakan melalui kegiatan tadharus dan hafalan Al-Qur'an (Tahfidzul Qur'an), shalat berjamaah, kegiatan kepramukaan, dan bela diri pagar nusa.

Pendidikan

karakter diimplementasikan dalam pembelajaran IPS mulai dari persiapan guru dalam pembelajaran hingga pembiasaanpembiasaan di dalam kelas seperti datang tepat waktu, bersalaman dan membuka dan mengakhiri pelajaran dengan membaca Al-Qur'an.

Metode yang digunakan guru IPS dalam penyampaian pendidikan karakter sebagian besar masih menggunakan metode ceramah, sehingga respon siswa terhadap pelaksanaan pendidikan karakter dalam pembelajaran IPS masih kurang maksimal.

Faktor pendukung pelaksanaan pendidikan karakter diantaranya adanya tata tertib, kultur sekolah, nilai kepesantrenan dan dukungan peran Kepala Sekolah dan Guru serta pihak yayasan. Faktor penghambatnya antara lain: sarana dan prasarana yang belum memadai, terbatasnya dana dan pembiayaan, program pembelajaran yang di antaranya alokasi waktu yang masih dianggap kurang dan juga metode yang digunakan dalam menyampaikan pendidikan karakter masih monoton, belum adanya buku penunjang tentang pendidikan karakter.

Berdasarkan pada kesimpulan, implikasi, dan keterbatasan penelitian, maka dapat durumuskan saran-saran sebagai berikut:

Kepada Pemerintah
Hendaknya memfasilitasi guruguru untuk mengembangkan modelmodel pendidikan karakter pada umumnya dan pada pembelajaran IPS khususnya serta memfasilitasi pelatihanpelatihan yang dapat mengembangkan kreativitas guru dalam pengembangan karakter.

\section{Kepada Pesantren}

Keterpaduan program pendidikan karakter yang sudah berjalan melalui kegiatan intra dan ekstra kurikuler serta dukungan nilai-nilai pesantren hendaknya diprogramkan secara sistematis untuk setiap program, sehingga jelas antara kegiatan utama dan pembinan karakter untuk setiap program, dan memudahkan pelaksanaannya di lapangan, serta membawa hasil yang maksimal.

Kepada Kepala Sekolah

Pihak kepala sekolah agar membentuk tim pengembangan pendidikan karakter secara terprogram, diawali dengan pengembangan programprogramnya (seperi RPP).

\section{Kepada Guru}

Guru hendaknya mengoptimalkan dengan mengembangkan metode yang lebih menarik dan inovatif dalam menanamkan pendidikan karakter dan pada pembelajaran IPS khususnya, serta memberikan teladan kepada siswa.

\section{UCAPAN TERIMA KASIH}

Kami ucapkan terima kasih kepada rekan-rekan di MA Ponpes Wahid Hasyim Yogyakarta atas dukungan doa dan semangat kepada penulis. Selain itu kami ucapkan terima kasih kepada pihak-pihak yang turut membantu support dana sehingga penelitian ini bisa berjalan dengan lancar. Terima kasih kepada redaksi yang telah mempublikasikan artikel hasil penelitian ini sehingga penelitian ini dapat dibaca oleh berbagai kalangan. Semoga hasil 
penelitian ini bermanfaat bagi perkembangan ilmu pengetahuan.

\section{DAFTAR PUSTAKA}

Arthur, J. 2003. Education With Character, The Moral Economy of Schooling. New York AS: 11 New Fetter Lane, London EC4P 4EE.

Elmubarok, Z. 2008. Membumikan Pendidikan Nilai. Bandung: Alfabeta.

(http://writingsdy.wordpress.com/2010 L12/01/pembelajaran-ips

Isjoni. 2007. Cooperative Learning. Bandung:Alfabeta.

Koesoma, D. 2010. Pendidikan Karakter Strategi Mendidik Anak Di Zaman Global. Jakarta: Gramedia.

Lickona, T. 1991. Educating For Character. How Our School Can Teach Respect And Responsibility. New York: Bantam Books. 2000. What Is Good Character? And How We Develop It In Our Children? Reclaming Children And Youth. Bloomington: Vol 9, Iss. 4; p.239 (13 page). Diambil pada tanggal 22 september 2011 dari http://proquest.umi.com/pqdwe b

. 2010. CEP's Eleven Principles Of Effective Character Education, 2010 Revision. Washington DC; Character Education Partnership dari

http://www.character.org/upload s/PDFs/eleven

Principles new2010.pdf).
Madjid, N. 1997. Bilik-Bilik Pesantren Sebuah Potret Perjalanan. Jakarta: Paramadina.

Montessori, M. 2008. The Absorbent, Pemikiran Yang Mudah Menyerap. Penerjemah Dariyatno. New York: Fifth Avenue.

Ma'arif, A.S. 1997.Pendidikan Islam Dan Proses Pemberdayaan Bangsa Dalam Muslih Musa dan Aden Wijaya (ed). Pendidikan Islam Dan Peradaban Industrial. Yogyakarta: Aditya Media

Nata, A. 2008. Manajemen Pendidikan. Mengatasi Kelemahan Pendidikan Islam di Indonesia. Jakarta: Prenada Media group.

Sjarkawi. 2006. Pembentukan Kepribadian Anak. Peran Moral, Intelektual, Emosional, Dan Sosial Sebagai Wujud Integritas Membangun Jati Diri. Jakarta: Bumi Aksara.

2008. Pembentukan Kepribadian Anak. Jakarta: Bumi Aksara.

Suwendi. 2004. Sejarah Dan Pemikiran Pendidikan Islam. Jakarta: Raja Grafindo Persada.

Undang-Undang Nomor 20 Tahun 2003 tentang Sistem Pendidikan Nasional (Sisdiknas) Pasal I ayat (1) Depdiknas. (2003). Undangundang RI Nomor 20, Tahun 2003, tentang sistem Pendidikan Nasional.

Winfred, F.F. 2010. Theories Of Learning: Survey of Psychological Interpretations. Penerjemah $\mathrm{M}$. Khozim. Bandung: Nusa Media. 